\title{
ANALYSIS AND RECONSTRUCTION OF LABORATORY ACTIVITIES DESIGN ON THE MATERIAL OF DIFFERENCES BETWEEN ANIMAL AND PLANT CELLS FOR TENTH GRADE STUDENTS
}

\author{
Nuris Fattahillah ${ }^{1)}$, Bambang Supriatno ${ }^{1)}$, Sri Anggraeni ${ }^{1)}$ \\ Indonesia University of Education \\ sayanurisfattah@gmail.com
}

\begin{abstract}
This research aimed to provide an overview of the practicum design regarding the differences between animal cell and plant cell used in Student Worksheet in Banyuwangi Regency. The samples used were 6 Student Worksheets of practicum work on animal and plant cells consisting of 3 Student Worksheets from the education unit level curriculum (hereafter, KTSP) and 3 Student Worksheets from the curriculum 2013. The sampling technique used in this research was purposive sampling. The instruments used were obtained from the Biology Education Lecturers Team of Indonesia University of Education which consisted of relevance aspect, Competency Aspect, practical aspect and knowledge construction analysis of Vee Diagram adapted from Novak \& Gowin (1984). The results of the analysis showed the following: 1.) relevance aspect, not in accordance with the demands of Basic Competence, 2.) Competency Aspect, there were no objects or phenomena that could be observed and the ability to think was only limited to C1, 3.) practical aspect, showing that the suitability of the tools, materials and practicum steps still did not meet the practicum standards, and 4.) the knowledge construction of title/objective had not been focused, the object of the phenomenon could not be observed and only a few theories, principles, and concepts could be identified. This shows that the role of Student Worksheet in practicum activities has not been optimal and practicum reconstruction is needed so that practicum activities can run optimally.
\end{abstract}

Keywords: Student Worksheet, practicum, Vee diagram

\section{INTRODUCTION}

Biology is one of the sciences that provide many learning experiences to understand the concepts and processes of science. The process skill in biology includes observing, categorizing, predicting, communicating, proposing hypotheses, planning experiments or investigations, applying concepts or principles, and asking questions (Nuryani, 2005: 78-81). The learning process can determine the quality of students' outcomes (Ardana and Rina, 2020).

The recent educational paradigm is developing rapidly. One of the developing paradigms is that learning biology is considered difficult because many things to learn (Jayawardana \& Rina, 2020). This is supported by Solikhatun et al. (2015), which state that most students consider biology is complex because it is a rote lesson, so that in classroom learning, students only listen and take notes from the teacher's explanation.
Sometimes there are misconceptions in the learning conducted.

Misconceptions can occur due to abstract and complex concepts that can make it difficult for students to understand (Ibrahim, 2012). One of the lessons that can create misconceptions is material about cell structure and function, according to Muller et al. (2007); Simanek (2007), in studying the cell structure and function, observations using a microscope can hinder the thinking process because of wrong logic after the observation takes place. To avoid misconceptions, teachers must explain in detail about learning activities and practicum activities. Practicum activities are essential in learning biology because they can help students connect two domains of knowledge that are objects or phenomena observed and the realm of ideas and can train cognitive, affective, and psychomotor abilities in understanding a biological 
phenomenon (Ulfa, 2016; Wahidah et al., 2018).

Laboratory-based learning activities can be used as an alternative to learning activities to explore and maximize students' learning potential through the first bioscience activity, where students can develop themselves in biology learning as part of science through laboratory-based activities (Croker, et al., 2010). Supriatno (2009) has researched 46 samples of Biology Student worksheets. The results showed that $24 \%$ of Student worksheets could be done according to procedures and got good or complete scores in terms of Analysis and conclusion, the remaining $76 \%$ had problems in several ways, namely: 1) unstructured work steps, 2) complex procedures to be done, 3 ) the data table was still rigid, and the results of the practicum caused misconceptions, 4) it was incomplete in the practicum, and 5) required a relatively long time in one experiment.

The problems in LAD (Laboratory Activity Design), according to Supriatno (2013), are that the practicum objectives emphasize more cognitive than psychomotor aspects. Most of LAD uses a deductive approach with an expository model; although detailed in LAD practicum procedures, some are unstructured. The orders are confusing, which causing multiple interpretations. However, the practicum is expected to change the students' mindset, and the learning becomes laboratory-based learning. According to Woolnough. (2003) stated the importance of doing a practicum are 1) it can generate students' motivation, 2) it can develop basic abilities in experimenting, 3) it becomes a vehicle for scientific approaches, and 4) can support learning materials, to avoid the existence of misconceptions about biology learning, especially on the material of cell structure and function.

The problems presented by Supriatno (2013) and (Rini et al., 2014) became the basis for the analysis of the Student Worksheet (LKS). It was found that the worksheets used in a practicum in schools did not meet the practicum objectives, and it was not even clear for the activities. Besides that, the practicum activities did not meet the curriculum's learning objectives and demands, so they needed to be reviewed. The researchers examined the use of Student worksheets on the material of differences between the structure of animal and plant cells because the material is abstract and can cause misconceptions (Jayawardana \& Rina, 2020).

Researchers analyzed the design of laboratory activities from several aspects, namely 1) Relevance Aspects (competence with BC and content with BC); 2) Competency aspect (observation, transformation, interpretation, and thinking ability); 3) Knowledge Construction Analysis adapted from Novak \& Gowin (1984), namely 1) title/objective; 2) the object of the phenomenon; 3) theories, principles, and concepts; 4) data recording and transformation; and 5) knowledge acquisition. The Analysis of the worksheets used 6 biology learning books for Xth grade consisting of 3 books from the KTSP curriculum and 3 books from the curriculum 2013 that had been refined.

This Analysis used the comparison between the previous and current curriculums to know the difference since the Student Worksheet of the KTSP curriculum has not described the sequence of learning in detail that caused interpretation that was diverse and led to teacher-centered learning and the Student Worksheet of the curriculum 2013 whose learning activities has been centered on students (Kemendikbud, 2016). In addition, the authors also reconstructed the Laboratory Activity Design (LAD) on observing animal and plant cells to improve practicum activities so that they can be used optimally and help students' thinking processes.

\section{RESEARCH METHOD}

The method used was a qualitative descriptive method. The purpose was to describe the phenomena found on the Student Worksheet being observed. The observed practicum was about the difference between animal and plant cells for Xth grade in Banyuwangi. The samples used in this research were 6 Student Worksheets consisting of 3 books from the KTSP, named Samples A, B, and C; and 3 books from the 
curriculum 2013 named Sample D, E, and F. The sampling was done through purposive sampling. The research instrument used an instrument developed by the Biology Education Lecturers Team, the Indonesia University of Education, which included analysis of relevance aspect, Competency Aspect, practical aspect, and knowledge construction analysis adapted from Novak \& Gowin, 1984), which consists of 1) title/objective; 2) the object of the phenomenon; 3) theories, principles and concepts; 4) data recording and transformation, and 5) knowledge acquisition.

The research began by analyzing the LAD published by publishers using instruments by the Biology Education Lecturer Team, Indonesia University of Education. After that, the LAD was tested according to the practical instructions in the book and analyzed for the weaknesses. After implementation, the researcher reconstructed the LAD by changing some of the LAD or the entire LAD that contained errors or incorrect procedures.

\section{RESULT AND DISCUSSION}

Before conducting trials on practicum activities, researchers analyzed the Laboratory Activities Design (LAD) on the Student Worksheet to be studied: the analysis of relevance aspect, competency aspect, practical aspect, and knowledge construction analysis. The relevance aspect was analyzing the activities and curriculum consisting of competence with $\mathrm{BC}$ and content with $\mathrm{BC}$, in the aspect of competence containing the ability to observe, transform, interpret, and level thinking skills and analysis of knowledge construction (Vee diagram) which was adapted from Novak \& Gowin (1984). The results of the analysis worksheets that referred to the aspect of relevance can be seen in Table 1.
Table 1. Relevance Aspect (Activities and Curriculum)

\begin{tabular}{clcccccc}
\hline & \multirow{8}{c}{ SW Score } \\
No. & Parameter & \multicolumn{3}{c}{ KTSP } & \multicolumn{3}{c}{ K. 13 } \\
& A & B & C & D & E & F \\
\hline 1. & $\begin{array}{l}\text { Competence } \\
\text { with BC }\end{array}$ & 1 & 2 & 1 & 2 & 1 & 1 \\
\hline 2. & $\begin{array}{l}\text { Content with } \\
\text { BC }\end{array}$ & 1 & 1 & 1 & 1 & 1 & 2 \\
\hline
\end{tabular}

Generally, the SW was following the practicum in general. It was in line with the curriculum both in terms of competence and content. However, for SW competence with BC, SW differs from the KTSP (Student Worksheet A, B, and C) and the curriculum 2013 (Student Worksheet D, E, F). The relevance of competence with $\mathrm{BC}$ had a value of 2 only in 2 Student Worksheets, namely Student Worksheet B from KTSP and D from curriculum 2013, which means that the competencies developed in the practicum met the minimum BC standards. Meanwhile, other worksheets regarding content with $\mathrm{BC}$ scored 1 , which means that the content in practicum activities did not meet $\mathrm{BC}$ standards.

In content with $\mathrm{BC}$, there was only 1 Student Worksheet (F) scored 2, which means the content in practicum activities met the BC minimum standard. In contrast, other Student Worksheets scored 1, which means the content in practicum activities did not meet the BC minimum standard. According to Handayani (2018), most of the schools that have implemented curriculum 2013 have carried out biology practicum in line with practical needs and also following essential competencies, while schools that have not implemented curriculum 2013 are primarily practicing below the frequency of utilization that should be or even not according to BC standards. Therefore, some worksheets in the KTSP curriculum did not match the relevance of competencies or content with BC compared to curriculum 2013.

The competency aspect analysis was the ability to observe, transform, interpret, and think ability levels. The results of the analysis can be seen in table 2 below. 
Table 2. Competency Aspect Analysis

\begin{tabular}{cccccccc}
\hline \multirow{3}{*}{ No. } & \multirow{3}{*}{ Parameter } & \multicolumn{4}{c}{ SW SKOR } \\
\cline { 3 - 7 } & & \multicolumn{4}{c}{ KTSP } & \multicolumn{4}{c}{ K 13 } \\
\cline { 3 - 8 } & A & B & C & D & E & F \\
\hline 1. & $\begin{array}{l}\text { Observation } \\
\text { Ability }\end{array}$ & 2 & 2 & 2 & 2 & 2 & 2 \\
\hline 2. & Transformation & 1 & 1 & 1 & 2 & 1 & 2 \\
\hline 3. & Interpretation & 2 & 1 & 2 & 2 & 1 & 2 \\
\hline 4. & $\begin{array}{l}\text { Thinking } \\
\text { ability level }\end{array}$ & 1 & 1 & 1 & 1 & 0 & 1 \\
\hline
\end{tabular}

In general, All SW of KTSP and curriculum 2013 practicum activities on observation ability have been directed towards observing the general character or the specific character of an object or phenomenon. On the observation ability in SW KTSP and curriculum 2013 have the same score that was 2, which means only observing the general character of the object or phenomenon. In data transformation, there were $60 \% \mathrm{SW}$ which had a score of 1 and $40 \%$ had a score of 2 . The analysis showed a higher score in curriculum 2013 that was 2 except for Student Worksheet E which scored 1, score of 2 indicated that the data were represented in standard form but quantitative data represented in other forms appropriately. Meanwhile, the KTSP curriculum had a score of 1 , which means that the data were represented in a standard form.

Regarding the interpretation competence, the student worksheet on either the KTSP curriculum or curriculum 2013 obtained the same score of 2 (A, C, D, and E), which means that the use of the data component as a whole, shown by qualitative data, in the observation of animal cells and plant cells was indicated by observational data in the form of images containing information of the organelles that can be observed. Other student worksheets obtained a score of 1 which means that the data were not interpreted and only used some data components. In the thinking ability level, it involved only the thinking level of $\mathrm{C} 1$ (mentioning) up to C3 (applying), except the student worksheet $\mathrm{E}$, which obtained a score of 0 , which did not involve thinking ability $\mathrm{C} 1$ (mentioning) up to $\mathrm{C} 3$ (applying). It was due to the student worksheet $\mathrm{E}$ had no question raised in its practicum; it just presented the image resulted from the observation.

According to Hamidah et al. (2014), one of the requirements in learning biology is practicum activities. Therefore, practicum activities must be carried out properly with good laboratory conditions. Practicum activities have an essential role in realizing the effectiveness of Biology learning. According to Supriatno (2009), if there were wrong work steps, there would be an ineffective result from the practicum. This ineffectiveness can cause the practicum less optimal; the students are not focused on the practicum and may do what should not be done. In addition to analysis, experiments were also carried out on SW to test the practical aspect of each student worksheet. The practice on the SW was carried out at SMAN 1 Banyuwangi on March 1, 2021, to find out what obstacles might occur during the practicum. The following Table 3 shows the results of the practical analysis.

Table 3. Practical Aspect Analysis

\begin{tabular}{|c|c|c|c|c|c|c|c|}
\hline \multirow{3}{*}{ No } & \multirow{3}{*}{ Parameter } & \multicolumn{6}{|c|}{ SW score } \\
\hline & & \multicolumn{2}{|c|}{$\begin{array}{c}\text { KTSP } \\
\text { curriculum }\end{array}$} & \multicolumn{4}{|c|}{$\begin{array}{c}\text { curriculum } \\
2013\end{array}$} \\
\hline & & $\mathrm{A}$ & B & $\mathrm{C}$ & $\mathrm{D}$ & $E$ & $\mathrm{~F}$ \\
\hline 1. & $\begin{array}{l}\text { The } \\
\text { suitability of } \\
\text { the } \\
\text { practicum } \\
\text { tools with } \\
\text { school } \\
\text { standards }\end{array}$ & 4 & 4 & 4 & 4 & 4 & 4 \\
\hline 2. & $\begin{array}{l}\text { The } \\
\text { suitability of } \\
\text { the } \\
\text { practicum } \\
\text { materials } \\
\text { with the } \\
\text { needs of the } \\
\text { activity }\end{array}$ & 2 & 2 & 3 & 3 & 2 & 2 \\
\hline 3. & $\begin{array}{l}\text { Practicum } \\
\text { Working } \\
\text { structure }\end{array}$ & 3 & 4 & 3 & 4 & 3 & 3 \\
\hline
\end{tabular}

The suitability of practicum tools with school standards in general, all Student Worksheet scored 4, means that all required practicum tools were available in the laboratory and accordance with school laboratory standards. On the suitability of practicum materials with the needs of the activity, only 2 Student Worksheets scored 
3, namely Student Worksheet C and D, which means that not all practicum materials needed were in line with school laboratory standards, and some practicum tools can be replaced with alternative materials. In contrast, some other Student Worksheets had scored 2, which means that some of the required practicum materials were not found in the school laboratory. For example, Student Worksheets B, E, and F did not use methylene blue in observations, even though this material is essential during observations so that observations on cells become easy. In Student Worksheet A, practical materials were not found in school laboratories, such as Hydrilla, which schools and students rarely provide, tended to find their own for the practicum materials.

In the practicum work structure, Student Worksheet B and D had a score of 4, which means that all work steps were structured and in order/stages to get the results of observations. In contrast, another Student Worksheet had a value of 3 which means all work steps were structured, but there were wrong sequences/stages of getting the results. The results of observations, this was because the stages of observation in animal and plant cells were not distinguished at the observation stage between animal and plant cells, even though it was essential to differentiate so that students knew the differences in treatment/observation methods in animal and plant cells, for example giving methylene blue to animal cells. Moreover, aquades in plant cells this was intended to facilitate observations and avoid misconceptions during observations. Supriatno (2009) strengthened this, stating that unstructured practicum work steps can lead to failure during practicum activities, and learning is less meaningful.

\section{Aspect of Knowledge Construction (Vee Diagram)}

After determining the knowledge construction of the Vee diagram, the six worksheets were also scored. The results of the scoring can be seen in Table 4 .
Table 4. Knowledge Construction of Vee Diagram

\begin{tabular}{llllllll}
\hline \multirow{2}{*}{ No } & Parameter & \multicolumn{9}{l}{ SW SCORE } & \multicolumn{4}{l}{} \\
\cline { 3 - 8 } & & $\begin{array}{l}\text { KTSP } \\
\text { curriculum }\end{array}$ & \multicolumn{4}{c}{ curriculum } \\
\cline { 2 - 7 } & A & B & C & D & E & F \\
\hline 1. & Title/Purpose & 2 & 2 & 2 & 2 & 1 & 2 \\
\hline 2. & $\begin{array}{l}\text { Phenomenon } \\
\text { object }\end{array}$ & 0 & 0 & 0 & 1 & 0 & 1 \\
\hline 3. & $\begin{array}{l}\text { Theories, } \\
\text { principles and } \\
\text { concepts }\end{array}$ & 2 & 2 & 2 & 2 & 0 & 2 \\
\hline 4. & $\begin{array}{l}\text { Data } \\
\text { recording and } \\
\text { transformation }\end{array}$ & 0 & 0 & 0 & 0 & 0 & 0 \\
\hline 5. & $\begin{array}{l}\text { Knowledge } \\
\text { Acquisition }\end{array}$ & 2 & 2 & 2 & 2 & 1 & 2 \\
\hline
\end{tabular}

The title/objective on the knowledge construction of the Vee diagram showed that almost all worksheets scored 2, which means the title/objective/focus question contained a conceptual part but did not support the observation of the main object or event. Student Worksheet E scored 1, which means that there were no questions on the focus, title, or purpose of the activity. For phenomenon objects, almost all worksheets scored 0 , meaning no objects or events can be identified. Student Worksheet D and F scored 1 , which means the main event or object can be identified and consistent with the focus question, or events and objects can be identified but not consistent with the focus question.

Object phenomena that can be observed from Student Worksheet, almost all Student Worksheet scored 0, meaning no objects or events were identified. In theory, principles, and concepts, almost all worksheets scored 2, namely concepts and approximately one principle (conceptual or methodological) or concepts, and a relevant theory can be identified. Student Worksheet E scored 0, which means no identifiable conceptual part because Student Worksheet E had no focus questions, principles, or concepts identified in the practicum.

Recording and transforming data for all Student Worksheets, there was no recording or data transformation activity identified. In knowledge acquisition, almost all Student Worksheets had a score of 2, namely the acquisition of knowledge was inconsistent with the data and events 
recorded and transformed, or knowledge acquisition already contained a conceptual side. In contrast, Student Worksheet E had a score of 1, namely, the acquisition of knowledge did not match the left side of the Vee diagram. Overall, the construction of knowledge was still not perfect, so it needed to be repaired and reconstructed to carry out the practicum in line with the standards. Students can gain the appropriate knowledge so that the practicum activities are meaningful.

Activities in the practicum need to pay attention to several things: title and objectives, tools, materials, procedures, and activities results. Tesch and Duit (2006:149) grouping the practicum stage into several parts, namely 1.) the preliminary stage, which plays an essential role as a student guide in practicum activities such as preparation and work steps, 2.) the work stage, which is the core stage for students. Students such as assemblers, observing, and so forth, and 3.) closing stage, ending with the end of the practicum, the results of observations, discussion, and closing. Apart from the activities, attention is needed to the laboratory state used as a place for practicum. According to Mustaji (2009:1), the laboratory can be a place for students to drill skills, practice, experiment, knowledge, demonstrate and develop knowledge.

The development of knowledge must also be in line with the holding of practicum. However, sometimes practicum can make students confused. According to Novak \& Gowin (1985), practicum activities can make students frustrated and confused when carrying out practicum activities. This is because the design of laboratory activities is not appropriate or has not become an easy guide for students, causing the practicum to be meaningless. For this reason, it is necessary to reconstruct appropriate practicum activities so that learning activities are appropriate and do not confuse students. Before that, the teacher must analyze the feasibility of the practicum and try it out before it is implemented in classroom learning. After being tested, the teacher can reconstruct the activities that are lacking or inappropriate in the practicum.
Student Worksheet Reconstruction Reconstructed Practicum Activity Sheet: Observation of Animal Cells and Plant Cells

Objectives:

1. Skilled in making preparations of animal cells and plant cells

2. Can use a microscope to observe cells

3. Can make preparations on animal and plant tissues

4. Can conclude the difference between animal cells and plant cells

Tool:

1. Microscope

2. Glass preparation

3. Cover glass

4. Dropping pipettes

5. Cutter/ Razor

6. Scalpel/cotton bud

7. Stationery

Material:

1. Aquades

2. Methylene blue

3. Tissue

4. $70 \%$ alcohol

5. Animal tissue: human cheek epithelium, mammalian intestinal epithelium (cow or goat), mammalian liver epithelium (cow or goat)

6. Plant tissue: onion bulbs, celery stem, and roots of dicotyledonous plants

Work steps:

1. Observing plant cells

- Prepare tools and materials to be observed

- Thinly slice the inner membrane of the onion bulbs, celery stem, and roots of dicotyledonous plants

- Place the slices of the preparation on a glass slide

- Add a drop of distilled water to the slices of the preparation carefully

- Cover with a coverslip and press with a clean thumb

- Clean excess water using a tissue

- Observe the plant preparations under a microscope with a small to large distribution

- Describe the results of observations in the report of observations carefully 
2. Observing animal cells

- Prepare tools and materials to be observed

- Clean the scalpel using $70 \%$ alcohol

- Gently wipe the epithelium of the cheek cavity, mammalian intestine, and mammalian liver using a scalpel or cotton swab

- Place the slices of the preparation on a glass slide

- Add a drop of methylene blue to the slices of the preparation carefully

- Cover with a coverslip and press with a clean thumb

- Clean excess water using a tissue

- Observe the plant preparations under a microscope with a small to large distribution

- Describe the results of observations in the report of observations carefully

- Experiment Result Data

\begin{tabular}{|l|l|l|l|l|}
\hline No & $\begin{array}{l}\text { Animal } \\
\text { cell } \\
\text { figure }\end{array}$ & Note & $\begin{array}{l}\text { Plant } \\
\text { cell } \\
\text { figure }\end{array}$ & Note \\
\hline 1. & & & & \\
\hline 2. & & & & \\
\hline
\end{tabular}

Questions:

1. What cell parts can be observed from plant cell preparations?

2. What cell parts can be observed from animal cell preparations?

3. What are the differences in the structure of animal cells and plant cells after observation?

4. What are the consequences of the difference between animal cells and plant cells?

5. What would happen if plant cells do not have a cell wall and vice versa in animal cells?

\section{CONCLUSION}

The analysis was carried out on 6 Student Worksheets consisting of 3 Student Worksheets from the KTSP curriculum and 3 Student Worksheets from the K.13 curriculum covering the analysis of relevance aspect, competency aspect, practical aspect, and knowledge construction analysis. The Vee diagram showed that the design of laboratory activities or student practicum worksheets had not met the complete SW components. Incomplete components resulted in nonoptimal and less meaningful practicum activities for students. Therefore, to adjust the quality of practicum on student worksheets, it is necessary to conduct Student Worksheets reconstruction according to practicum standards to maximize practicum activities. Students can gain complete knowledge so that practicum activities are meaningful.

\section{REFERENCES}

Croker, K., Andersson, H., Lush, D., Prince, R., \& Gomez, S. 2010. Enhancing the student experience of laboratory practicals through digital video guides. Bioscience Education, 16 (1), 1-13. https://doi.org/10.3108/ beej. 16.2

Hamidah, A., E. N. Sari, \& R. S. Budianingsih. 2014. Persepsi Siswa tentang Kegiatan Praktikum Biologi di Laboraturium SMA Negeri SeKota Jambi. Jurnal Sainmatika. 8 (1). ISSN 1979-0910

Handayani, Meni. 2018. Pemanfaatan Sarana Laboraturium di SMA yang Telah dan Belum Melaksanakan Kurikulum 2013. Jurnal Pendidikan dan Kebudayaan. 3 (2). DOI: 10.24832/jpnk.v3i2.658

Ibrahim, M. Konsep Miskonsepsi dan Cara Pembelajarannya. Surabaya: Unesa University Press

Jayawardana, H. B. A., \& R. S. D. Gita. 2020. Inovasi Pembelajaran Biologi di Era Revolusi Indusri 4.0. Prosiding Seminar Nasional Biologi di Era Pandemi COVID-19. ISBN: 978-60272245-5-1

Muller, D. A., Sharma, M. D., Eklund, J. and Reimann, P. 2007. "Conceptual change through vicarious learning in an authentic physics setting", Instructional Science. 35 (6): 519-533

Mustaji, 2009. Teknologi Pengajaran. http://pasca.tp.ac.id/site/laboratorium 
perspektif-teknologi-pembelajaran

(Diakses tanggal 22 Mei 2021)
(Era Otonomi Daerah). Yogyakarta: UUP STIM YKPN

Nuryani. 2005. Strategi Belajar Mengajar

Biologi. Malang: IKIP Malang Press

Novak and Gowin. 1985. Learning How to Learn. New York: Cambridge University Press

Permendikbud No. 22 .2016. Standar Proses Pendidikan Dasar dan Menengah. Jakarta: Kementrian Pendidikan dan Kebudayaan

Rustaman, N., Dirdjosoemarto, S., Yudianto, S. A., Achmad, Y., Subhekti, R., Rochintaniawati, D., \& Nurjhani, M. 2003. Strategi belajar mengajar biologi. Malang: UM Press

Simanek, D. E. 2017. "Didaktikogenic Physics Misconceptions", http://www.lhup.edu/dsimaneklscenario/miscon.htm (Diakses tanggal 20 Mei 2021)

Solikhatun, Imah; Slamet Santosa; \& Maridi. 2015. Pengaruh Penerapan Reality Based Learning Terhadap Hasil Belajar Biologi Siswa Kelas X SMA Negeri 5 Surakarta Tahun Pelajaran 2012/2013. Jurnal Pendidikan Biologi. 7 (3): 49-60

Supriatno, B. 2009. Uji langkah kerja laboratorium biologi sekolah. dalam Proseding Seminar Nasional Jurusan Pendidikan Biologi. Bandung: Universitas Pendidikan Indonesia

Supriyatno, B. 2013. Pengembangan Program Perkuliahan Pengembangan Pratikum Biologi Sekolah Berbasis ANCORB untuk Mengembangkan Kemampuan Merancang dan Mengembangkan Kemampuan Merancang dan Mengembangkan Desain Kegiatan Laboratorium. Disertasi Jurusan Penidikan Biologi FMIPA UPI: Tidak diterbitkan

Ulfa, Syarifah. 2016. Pembelajaran Berbasis Praktikum: Upaya Mengembangkan Sikap Ilmiah Siswa Pada Pembelajaran Biologi. Jurnal Pendidikan Islam dan Teknologi Pendidikan. 6 (1).

Widodo, Tri. 2006. Perencanaan Pembangunan. Aplikasi Komputer 